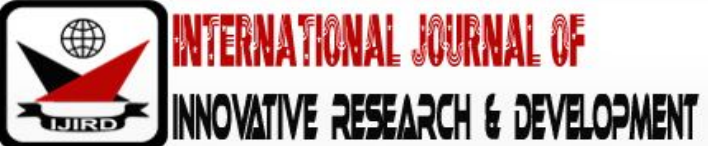

ISSN 2278 - 0211 (Online)

\section{Relationship between Principals' Participation in Academic Activities and Students' Academic Performance in Public Secondary Schools in Kakamega County, Kenya}

Justus Barasa Maende
Ph.D. Candidate, Department of Educational Management and Policy Studies,
Masinde Muliro University of Science and Technology, Kenya
Dr. Stephen O. Odebero
Ag Deputy Principal, Department of Administration and Finance,
Turkana University College, Kenya
Dr. Limukii Kaberia
Lecturer, Department of Educational Planning and management,
Masinde Muliro University of Science and Technology, Kenya

\begin{abstract}
:
Secondary school principal is expected to use leadership styles to enhance students' academic performance. There has been a decline in the percentage of the Kenya Certificate of Secondary Education (KCSE) examination candidates from Kakamega County who were selected to join public universities. For instance, in the years 2011, 2012, 2013, 2014 and 2015, 15.53\%, $14.84 \%, 13.47 \%, 12.61 \%$ and $12.24 \%$ of the candidates respectively were selected to join universities. This was contrary to the national rising trend where $7.18 \%, 9.12 \%, 10.17 \%, 12.11 \%$ and $12.72 \%$ of the KCSE candidates in the years 2011, 2012, 2013, 2014 and 2015 respectively were selected to join public universities. This declining trend could hinder the realization of Sustainable Development Goals and Kenya's Vision 2030. This study intended to establish the relationship between principals' participation in academic activities and students' academic performance. The study was guided by the Transformational leadership model and a conceptual framework. Correlational and descriptive survey designs were adopted. Respondents were sampled by simple random sampling. Pre-testing of questionnaires for teachers and students was undertaken to ensure validity and reliability of the instruments. Data was collected from 30 principals, 199 teachers and 393 Form 4 students by use of questionnaire and interview schedule. Research experts determined validity of the instruments. Data was analyzed using descriptive statistics, frequencies, percentages, cross tabulation and Pearson's correlation. Hypotheses were tested through regression analysis at 0.05 level of significance. Results show that principals' participation in invigilating exams, departmental/ subject meetings, releasing exam results, conducting academic/ career counseling and being KNEC examiners had positive correlations with academic performance. Regression analysis reveals that principals' participation in academic activities explained $28.7 \%$ of the variation in academic performance. Leadership styles such as principals invigilating exams, attending meetings of subject of specialization, conducting academic/career counseling and being a KNEC examiner significantly relates to academic performance. It was recommended that principals should adopt leadership styles that significantly relates to academic performance. This study would be significant to policy makers, principals, teachers and other education stakeholders in Kenya. The study would also form baseline information for future research.
\end{abstract}

Keywords: Leadership styles, principals' participation, academic activities, students' academic performance

\section{Introduction}

\subsection{Background Information}

It is in schools that education takes place and it is there that the success or failure of the national educational objectives will be determined (Akyeampong, 2007). The most outstanding factor has to do with the organisational management of schools. For instance, Chimombo (2009) and Dakar Forum (2001) note that to improve students' performance, principals are required first to improve the management of the schools. This can be done by setting a clear vision for the schools and communicate this vision to the students, support its achievement by giving instructional leadership, provision of resources and being visible in every part of the institution. Lack of vision in the management of schools often leads to imbalance in the allocation and use of resources. This is why Day (2005) points out that, poor results in education are related to the resources allocated to it. If this parameter is not recognized, it becomes very difficult to understand why a school continues to perform poorly in national examinations. For example, in schools where parents are 
doing their best in providing school facilities such as science equipment, textbooks and physical structures, the blame for poor performance is shifted to teachers (Daaku, 2002). Both the government and parents expect teachers to perform better at their present levels of training. The whole issue of students' performance should be considered from the broad framework of input and output.

The education system in Kenya is largely examination oriented. Kenya is ranked $17^{\text {th }}$ out of 54 countries in terms of efficiency in education sector based on students' performance, staff turnover, motivation and managerial competence (World's Competitiveness Report, 2009). Educational leadership in the 21st Century is expected to be focused for purpose of realizing the SDGs and Kenya's vision 2030. This requirement necessitates a leadership that is clearly defined for all involved. Leadership involves authority and responsibility in terms of deciding the way ahead and being held responsible for the success or failure of achieving the agreed objectives. World Bank (2008) observes that the increase in secondary education necessitates instituting responsible leadership in secondary education institutions. Performance of the academic institutions in meeting the goals and objectives of education in Kenya relies heavily on the type of leadership that prevails in the institutions and that many schools still perform poorly due to poor leadership. According to Mobegi, Ondigi and Oburu (2010), the quality of principals is a relevant indicator of quality in schools and therefore underscored the importance of head teachers in school administration. To this extent, the Ministry of Education introduced a Diploma in Educational Management for head teachers and principals. The course administered by the Kenya Education Management Institute (KEMI) is meant to equip the school managers with requisite skills to manage and implement educational policies in a contemporary education sector (MoE, 2011).

According to Lumosi and Mukonyi (2015), performance in the KCSE national examinations gives a picture of the level and quality of education and that Kakamega East and Kakamega central sub-counties experienced fluctuating results showing average and unsatisfactory academic performance over a period of five years from 2010 to 2014 . To effectively run a school, the principal is central in setting the tone of the school employing various management styles, which ensures effective teaching and learning by teachers and students respectively. One of the hailed leadership skill is participatory where subordinates have a stake in decision-making, there is good communication and delegation of responsibility and authority. This study therefore sought to establish the relationship between principals' participation in academic activities and students' academic performance in Kakamega County of Kenya.

\subsection{Statement of the Problem}

Secondary schools continue to face pressure to attain these set standards and there are continuous efforts to improve student academic performance (World Bank, 2008). Quality education in Kenya and world over is measured in terms of performance in examinations among other aspects. According to Kenya University and Colleges Central Placement Service (KUCCPS), in the years 2011, 2012, 2013, 2014 and 2015, there were 337,404, 357,488, 411,783, 437,762 and 449,246 candidates respectively registered for KCSE examination. Of these, 24,221; 32,611;41,879; 53,010 and 57,150 of the candidates were selected to join Public Universities in Kenya in the years 2011, 2012, 2013, 2014 and 2015 respectively. This shows that $7.18 \%, 9.12 \%, 10.17 \%, 12.11 \%$ and $12.72 \%$ of the KCSE candidates in the year 2011, 2012, 2013, 2014 and 2015 respectively were selected to join public universities. It is therefore evident that the percentage of the KCSE candidates who were selected to join public universities increased from 2011 to 2015. According to the Kakamega County Director of Education, in the years 2011, 2012, 2013, 2014 and 2015 were 11,742, 12,154, 14,987, 16,205 and 18,741 candidates respectively registered for KCSE examination. Out of these, 1,824, 1,804, 2,018, 2,044 and 2,294 of the candidates were selected to join public universities in Kenya in the years 2011, 2012, 2013, 2014 and 2015 respectively. This indicates that the percentage of the KCSE candidates who were selected for public university admission in the years 2011, 2012, 2013, 2014 and 2015 was 15.53\%, 14.84\%, 13.47\%, 12.61\% and 12.24\% respectively. This shows that there has been a decline in the percentage of KCSE candidates from Kakamega County who were selected to join public universities. This declining trend if allowed to go on may easily hinder the realization of SDGs and the Kenya's vision 2030. This study therefore sought to establish the relationship between academic activities implemented and students' academic performance in public secondary schools in Kakamega County of Kenya.

\subsection{Objective of the Study}

The specific objective of this study was to establish the relationship between principals' participation in academic activities and students' academic performance in public secondary schools in Kakamega County of Kenya.

\subsection{Research Hypothesis}

This study was guided by the following hypothesis:

$\mathrm{Ho}_{1}$. There is no significant relationship between principals' participation in academic activities and students' academic performance in public secondary schools in Kakamega County of Kenya.

\subsection{Scope of the Study}

This study covered the relationship between principals' participation in academic activities and students' academic performance in public secondary schools of Kakamega County, Kenya. The study involved principals, teachers and Form 4 students as respondents. Data was collected by use of questionnaire and interview schedule.

\subsection{Limitations of the Study}

Since the study touched on the principal who was the chief executive officer in the school, some respondents were hesitant to give information and others were suspicious of the outcome of the study and therefore remained guarded in 
giving information in fear of victimization or discipline from the principal. This was overcome by the researcher informing them that the information was for the purpose of research only and would be treated with utmost confidentiality. In addition, it was overcome by corroborating data collected from different respondents. At the same time, to control the intervening variables, the researcher employed random sampling technique and collected data from a large proportion of respondents.

\subsection{Significance of the Study}

This study was expected to provide valuable insights on students' academic performance in public secondary schools to researchers in the education sector who can use the research findings to analyze the relationship between principals' participation in academic activities and academic performance in secondary schools in Kenya. This knowledge may also be used in evaluating the success of principals as leaders and provide information to policy makers and implementers who can use the information in designing strategies that can be used to enhance students' academic performance by appointing appropriate teachers to become principals. The findings of the study may also provide the stakeholders in education with data on how principals participate in academic activities in secondary schools and in turn, the Government through the Ministry of Education may use the findings of this study to develop in-service training programmes at Kenya Education Management Institute (KEMI) that may help the principals adopt strategies that can enhance students' academic performance. The study may contribute through the development of new knowledge, which the teachers, principals and other education stakeholders can use to deal with the emerging issues in the students' academic performance.

\subsection{Theoretical Framework}

The study was based on the Transformational Leadership Model, which was conceived by Burns (1978) and improved on by Bass (1998). Burns (1978) first introduced the concept of transforming leadership in his descriptive research on political leaders, but this term is now used in organisational psychology as well. According to Burns, transforming leadership is a process in which "leaders and followers help each other to advance to a higher level of morale and motivation". Burns related to the difficulty in differentiation between management and leadership and claimed that the differences are in characteristics and behaviors. According to Burns, the transforming approach creates significant change in the life of people and organisations. It redesigns perceptions, values and changes expectations and aspirations of employees. Another researcher, Bass (1998), extended the work of Burns (1978) by explaining the psychological mechanisms that underlie transforming and transactional leadership. Bass also used the term "transformational" instead of "transforming." Bass added to the initial concepts of Burns (1978) to help explain how transformational leadership could be measured, as well as how it impacts follower motivation and performance. The extent, to which a leader is transformational, is measured in terms of his effects on the followers. The followers of such a leader have trust, admiration, loyalty and respect for the leader and because of the qualities of the transformational leader; they are willing to work harder than originally expected. These outcomes occur because the transformational leader offers followers something more than just working for self-gain; they provide followers with an inspiring mission and vision and give them an identity. Finally, in contrast to Burns, Bass suggested that leadership could simultaneously display both transformational and transactional leadership.

This model was related to this study in that it identified the leader in this case the principal as a mentor and role model who affect the followers (teachers and students) to produce excellent results (students' academic performance). It also clarifies that the leader and the followers work as a team in unity and celebrate these results together. It was based on this that the study sought to establish the relationship between principals' participation in academic activities and academic performance of the students in public secondary schools in Kakamega County of Kenya.

\subsection{Conceptual Framework}

A conceptual framework that shows the interaction of variables guided this study.

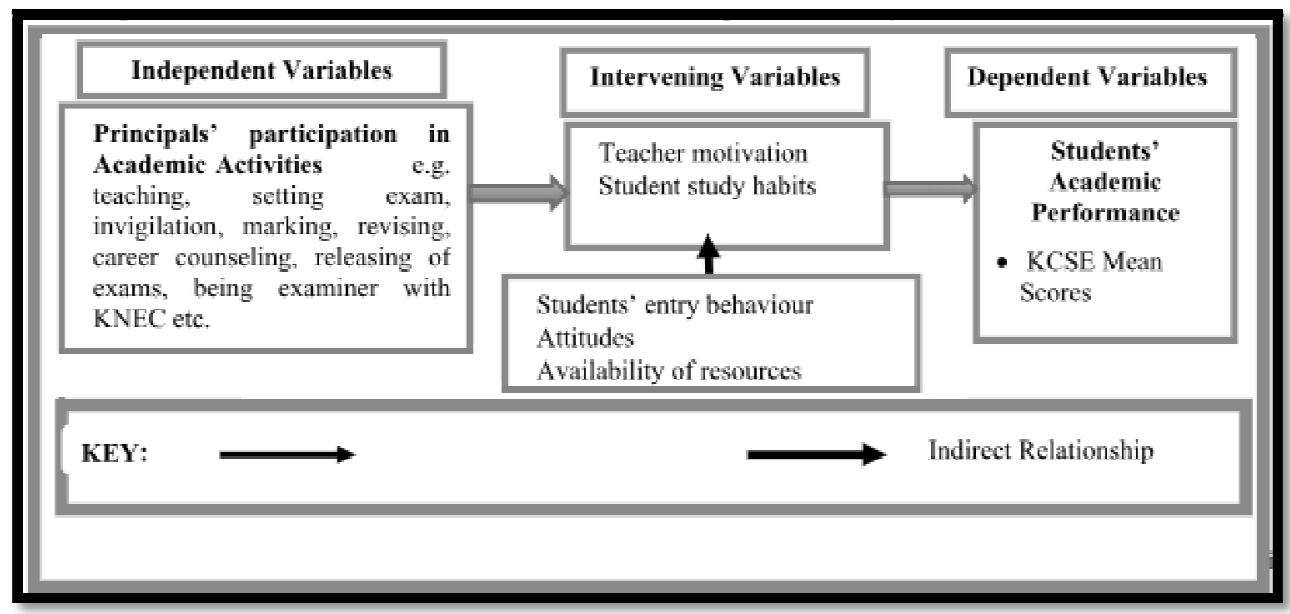

Figure 1: Relationship between Principals' Participation in Academic Activities and Students' Academic Performance

Source: Researcher (2016) 
Figure 1, displays interaction of variables between principals' participation in academic activities and students' academic performance. The independent variable of the study is principals' participation in academic activities. This influences teacher motivation, teacher effectiveness and student study habits that in turn influence the dependent variable that is students' academic performance that was measured by the mean scores in KCSE examination. However, independent and dependent variables do not occur in a vacuum. They operate in an environment. Therefore, intervening variables such as attitude, entry behaviour and availability of resources come into play and indirectly affect the students' academic performance. These factors when they complement principal's participation in academic activities, there is higher teacher motivation, effective teachers and good student study habits which lead to higher mean scores and quality student grades in KCSE examinations are realized. However, the opposite would occur when there is weak entry behaviour, negative attitudes and inadequate resources leading to low teacher motivation, less effective teachers and poor student study habits. This would ultimately contribute to poor academic performance in KCSE examinations.

\section{Materials and Methods}

\subsection{Research Design}

Research design can be defined as the means to collect data in order to answer questions concerning current status of the subject in the study (Okoth, 2012 \& Clark, 2009). This study employed both descriptive survey and correlational research designs. Descriptive survey is an observational research design that focuses on determining the status of a defined population, phenomenon, situation or condition being studied (Mugenda \& Mugenda, 2003). It establishes the pertinent facts that the research intends to establish without necessarily manipulating the variables of the study (Koul, 1992). Blaxter (1996) states that survey research in education involves the collection of information from members of a group of students, teachers or other persons associated with the educational process and the analysis of this information to address important educational issues while Bell (1999) indicates that descriptive survey necessitates data collection to provide information about existing status of the phenomenon on the ground. According to Orodho (2009), correlational design analyses the relationship between variables with the aim of establishing between the dependent and independent variables. In this case, this study sought to establish relationships between principals' leadership styles and students' academic performance and making predictions once the survey identifies and accurately describes the important variables in the study. These designs were deemed appropriate because they have been found to offer to social scientists and educators a systematic and logical method of collecting data for the purpose of measuring sample characteristics and establishing facts that result in formulation of important principles of knowledge about populations that are too large to be observed directly (Mugenda \& Mugenda, 2003; Koul, 1992).

\subsection{Location of the Study}

Kakamega County is located in the former Western Province of Kenya. It has a population of 1,660,651 and an area of 3,224.8 $\mathrm{km}^{2}$. The county lies between latitudes $0^{\circ} 30^{\prime}$ North and $0^{\circ} 25^{\prime}$ North and longitudes $34^{\circ}$ East and $35^{\circ}$ East. It has 11 constituencies namely: Lugari, Ikolomani, Mumias East, Mumias West, Likuyani, Malava, Navakholo, Shinyalu, Butere, Lurambi and Khwisero (IEBC, 2013). It is located at an altitude of 1520 - 1680 metres above sea level. The rainfall amounts of the study area range from about $1200 \mathrm{~mm}$ p.a to $2000 \mathrm{~mm}$ p.a which is bimodal (occurs in two rainy seasons that is the long and short rains) with the long rains occurring in the month of April to June while the short rains occurring in the month of October to November and short dry season in the month of December to March. The rainfall is distributed more or less uniformly throughout the year except for the month of November to February. The daytime temperature is about $30.8^{\circ} \mathrm{C}$ whereas at night they drop to up to $9^{\circ} \mathrm{C}$ with yearly mean of about $20.5^{\circ} \mathrm{C}$. The main economic activity in the study area is agricultural with $62 \%$ of the population involved in agriculture and mainly crop farming especially maize and beans are grown in the area for subsistence use. Sugarcane farming is major agricultural activity of the area and mainly done on large scale. Animal keeping of local breeds and dairy farming is also practised on small scale. The County had 292 public secondary schools by the time of the conceiving this study.

\subsection{Study Population}

The target population refers to an entire group of individuals, events or objects having common observable characteristics from which a sample that is a smaller group is obtained. It defines the universe of the study (Ghauri \& Gronhaug, 2005). The target population of this study consisted of 292 principals, 1,984 teachers and 18,741 Form 4 students drawn from 292 public secondary schools in Kakamega County of Kenya bringing the total to 21,017 individuals. The accessible population consisted of 30 schools selected by random sampling from among the 292 public secondary schools.

\subsection{Sample Size and Sampling Procedure}

\subsubsection{Sampling Procedure}

Sampling is a procedure of selecting a smaller and manageable proportion of the accessible population and that simple random sampling represents the most basic statistical sampling technique (Nassiuma, 2000). According to Kothari (2004) and Kerlinger (1993), $10 \%$ to $30 \%$ of a population is considered a good representative of the population. In the current study therefore, $10 \%$ of 292 schools is 30 while $10 \%$ of 1984 teachers is 199 . Sampling of schools involved writing names of all schools on pieces of paper and putting them in three containers, the first one with a series of high performing schools, the second one with average performing schools and the third one with low performing schools. The pieces were rolled into balls and thoroughly mixed. Ten pieces were then randomly drawn from each of the containers. This procedure 
was used because it provided an efficient mechanism for capturing the heterogeneity that existed in the target population (Kothari, 2004; Mugenda \& Mugenda, 2003; Blaxter, 1996). Therefore, 30 principals were sampled by purposive sampling because of the offices they held. Simple random sampling was used to give each of the teachers and students an equal chance to respond and involved the use of a table of random numbers to select 199 teachers and 393 Form 4 students to respond. The 393 Form 4 students were determined based on Israel (1992)'s formula of determining sample size as follows:

$$
n=\frac{N}{1+N(e)^{2}}
$$

Where, $\mathrm{n}=$ sample size, $\mathrm{N}=$ population size, $\mathrm{e}=$ the level of precision

$$
n=\frac{21741}{1+(0.05)^{2} 21741}=\frac{21741}{55.35}=393 \quad \text { Form } 4 \text { Students }
$$

This formula was considered appropriate based on the view of Israel (1992), that the formula could be used to determine a sample size for a larger population of over 2000. Form 4 students were selected because they had more experience with the principals and teachers in their schools and could give necessary information compared to the students in the lower classes who had less experience. This sample was considered appropriate based on the view of Dooley (2001), which indicates that a study, which probes deeply into the characteristics of a small sample, will often provide more knowledge than a study, which looks at the same problem by collecting shallow information from a large sample. Stratified sampling was used to place schools into three categories depending on their status as High Performing (HP), Average Performing (AP) or Low Performing (LP) Schools.

\subsubsection{Sample Size}

According to Mugenda and Mugenda (2003), sample size refers to the actual number of subjects chosen as a sample to represent the population characteristics. Sample size is affected by such factors as the number of variables in the study, the type of research design, the method of data analysis and the size of the accessible population and one has to balance between systematic bias and sampling error (Ghauri \& Gronhaug, 2005; Kothari, 2004; Israel, 1992). A total sample of 622 respondents was used in the study. In constructing the sample, the researcher embraced the recommendation of Kathuri and Pals (1993) that the minimum thresholds of 100 cases in major subgroups and 20 - 50 cases in minor subgroups was appropriate for surveys. Students and teachers in the schools constituted major subgroups from which 393 and 199 students and teachers were picked respectively. On the other hand, principals constituted a minor subgroup from which 30 principals were picked to respond. A sample size of respondents used is as shown in Table 2.

\begin{tabular}{|c|c|c|c|c|}
\hline Category of Respondents & Population (N) & $\begin{array}{c}\text { Sample } \\
\text { (n) }\end{array}$ & $\begin{array}{c}\text { Percentage } \\
\text { (\%) })\end{array}$ & Sampling Technique \\
\hline Principals & 292 & 30 & 10.27 & Purposive \\
\hline Teachers & 1,984 & 199 & 10.03 & Simple Random \\
\hline Students & 21,741 & 393 & 1.81 & Simple Random \\
\hline Total & 24,017 & 622 & 2.59 & \\
\hline
\end{tabular}

Table 2: Sample Size

Source: Kakamega County Director of Education (2014)

\subsection{Data Collection Instruments}

This study used both questionnaires and interview schedules as instruments for collecting data from respondents. Questionnaires were used to collect information from students and teachers. Questionnaires have the advantage of having everyone in each sampled category answer exactly the same questions, thereby making it possible for a few people to administer the questionnaires without affecting the validity and reliability of the instruments (Ghauri \& Gronhaug, 2005). It was therefore possible to reach out on a large number of respondents quickly, easily and efficiently using questionnaires. Interview schedules were used to collect data from principals who were helpful in clarifying issues that were not clearly articulated in questionnaires. As information collecting tools, interview schedules had inbuilt flexibility, since the interviewer had leeway to adapt to situations in order to get more detailed information. According to Kathuri and Pals (1993), interview schedules also outline questions that form the basis for and a guide to the interviewing process, which helps in standardizing the interview situation.

\subsubsection{Questionnaire}

Hague (1998) points out that primarily the role of questionnaire is to draw accurate information from the respondent. Bell (1999) noted that questionnaires are a good way of collecting certain types of information quickly and relatively cheaply. The questionnaire is an ideal instrument to gather descriptive information from a large sample in a fairly short time (Kothari, 2004). It can also be answered at the convenience of the respondent and picked at a later time. The selfdesigned questionnaires had both open ended and closed questions. The questionnaire was administered to teachers and students. The respondents were assured that the information given was only for the purpose of research and thus treated 
with utmost confidentiality. It was expected that the questionnaire would gather information from teachers on the relationship between principals' participation in academic activities and students' academic performance.

\subsubsection{Interview Schedule}

According to Kerlinger (1993), an interview is a face-to-face interpersonal role situation in which one person, the interviewer, asks the person being interviewed the responded some questions. The interview schedule was used for the principals. Creswell (2012) observes that interviews allow an in-depth insight into how individuals comprehend and relate various aspects. The interview schedule was used to get clarification of issues, which needed probing as well as assess the accuracy and genuineness of responses given by teachers and students on the principals' participation in academic activities and how it is related to students' academic performance.

\subsection{Pretesting of Instruments}

Pretesting is the administration of data collection instruments with a small set of respondents from the population for full-scale survey. This is done to anticipate problems that may be encountered during data collection (Kothari, 2004). For instance, terminologies used in questionnaires and interview schedules may not be understood by respondents or information to be retrieved from documents may not be readily available. Reducing error to acceptable levels therefore requires pretesting of data collection instruments. According to Orodho (2009), piloting is carried out to ensure that there is clarity and efficiency of instruments before the real study is carried out. All instruments were pre-tested in three schools that were part of the target population for the study, but which had not been sampled for the actual study. By examining responses from subjects after piloting, shortcomings that may have posed threats to validity and reliability of the instruments were addressed. This improved the effectiveness of instruments in collecting relevant data.

\subsubsection{Validity of Instruments}

According to Zeller (1997), validity refers to the degree to which an instrument measures what it is supposed to measure for a particular purpose and a particular group. A measure is valid if it measures what it is intended to measure (Keeves, 1997). According to Bell (1999), validity tells us whether an item measures or describes what it is supposed to measure or describe. Research experts validated the instruments of data collection for this study. The instruments were presented to the research experts. The experts provided suggestions that were used to revise the instruments. In addition, pre-testing was conducted and the responses from the respondents were used to improve the items.

\subsubsection{Reliability of Instruments}

Quality of research is dependent on the consistency with which observations are made. Consistency is in turn dependent on the precision with which an observation is specified (Keeves, 1997). Kosecoff (1998) explained that reliability is the degree of consistency between measures obtained from a subject under similar conditions at different times. A reliable survey will provide a consistent measure of important characteristics despite background fluctuations. Test-retest method of estimating reliability was used to determine the reliability. This method administers the same instrument twice to the same group of subjects at different times.

A pilot study was done in 3 schools that were not part of the actual study. The researcher administered the instruments to the students, teachers and the principals. After a period of two weeks the researcher administered the instruments again to the same respondents. Responses from the respondents were thus checked for consistency. From their responses, changes were made to the structure and some of the questions. In the analysis, the sum variables were compared to a single variable (Bryman \& Cramer, 2001). Cronbach's Coefficient, alpha, was computed to determine how the items correlated among themselves. This technique was preferred because it is known to give more conservative estimates of reliability as its estimated coefficient is always lower (Mugenda \& Mugenda, 2003). It was better to underestimate than to overestimate reliability to avoid making erroneous conclusions. The reliability index of 0.82 and 0.87 was obtained for students' questionnaire and teachers' questionnaire respectively. According to Koul (1992) and Sarantakos (1998), reliability index of 0.70 or higher is acceptable threshold for making inferences in a study. Therefore, the reliability indices obtained were deemed appropriate for use in this study.

\subsection{Data Collection Procedure}

Data is collected for the purpose of gathering information to serve or prove some fact. This requires one to follow approved procedures which guarantee adherence to ethics during research. Central to these ethics is the need to inform respondents about the nature of information sought and the use to which it will be put. This enables respondents to make informed decisions to participate in the research.

A research permit was sought to enable unhindered collection of data in Kakamega County, Kenya. The schools were categorized into high performing schools (HPS), average performing schools (APS) and low performing schools (LPS). Schools were sampled based on their strata. The research instruments were piloted in 3 schools that were not part of the actual study. Principals in the sampled schools were approached where questionnaires were administered to the sampled teachers and students. Two research assistants were trained to be conversant with the study and involved in the collection of data. Interviews and document analysis were also used to collect data concurrently with the questionnaire administration. Confidentiality was upheld at all times. This was to address ethical issues during the research. 


\subsection{Data Analysis Procedures}

The sources of analyzed data included questionnaires, interview schedules and school records. The quantitative data obtained from close-ended parts of the questionnaire were coded in readiness for standardized statistical analysis techniques using statistical package for social sciences (SPSS) version 20.0 for analysis. Qualitative data was transcribed, grouped into themes and sub-themes as they emerged. Quantitative data was analyzed by descriptive and inferential statistics and presented in form of frequency tables, means and percentages. For better interpretations and pictorial view, data was further presented as bar graphs and pie charts. Cross tabulations, Pearson's correlation coefficient and Multiple Linear Regressions were used to establish relationships between variables. All statistical inferences were done at $\alpha=0.05$.

\section{Findings and Analysis}

\subsection{Academic Activities That Principals Participated in}

This study examined academic activities that principals participated in and the results are shown in Table 3.

\begin{tabular}{|c|c|c|}
\hline $\begin{array}{c}\text { Areas of Participation } \\
\text { n = 199 }\end{array}$ & Frequency (F) & Percentage (\%) \\
\hline Officiating all exam results release ceremonies & 194 & 97.5 \\
\hline Allocated lessons on timetable & 181 & 91.0 \\
\hline Carrying out academic/ career counseling & 105 & 52.8 \\
\hline Invigilation/ Supervising Examinations & 102 & 51.3 \\
\hline Attending Departmental/ subject meetings & 82 & 41.2 \\
\hline Marking KCSE examination (Examiner with KNEC) & 73 & 36.7 \\
\hline Attending lessons to teach in his/ her subject area & 67 & 33.7 \\
\hline Setting Examination in his/ her Subject Area & 66 & 33.2 \\
\hline Marking Examination in his/ her Subject Area & 61 & 30.7 \\
\hline Filling Record of work covered book & 42 & 21.1 \\
\hline
\end{tabular}

Table 3: Academic Activities that Principals participated in Source: Field data (2016)

From Table 3, it is clear that 194 (97.5\%) of the teachers reported that principals in their schools officiated all exam results release ceremonies while 181 (91.0\%) of them indicated that their principals were allocated lessons on the timetable. At the same time, 105 (52.8\%) of the teachers reported that their principals carried out academic / career counseling while another 102 (51.3\%) of the teachers indicated that their principals invigilated/ supervised examinations in their schools. Furthermore, $82(41.2 \%)$ of the teachers indicated that their principals attended departmental or subject meetings in their areas of specialization while 73 (36.7\%) of them reported that their school principals were examiners with KNEC; thus, they marked KCSE examination. Furthermore, 67 (33.7\%) of the teachers indicated that principals in their schools attended lessons to teach in their subject area while $66(33.2 \%)$ of the teachers reported that principals participated in setting examination in their subject area. At the same time, 61 (30.7\%) of the teachers indicated that principals in their schools marked examinations in their subject area while another $42(21.1 \%)$ of them reported that principals in their schools filled record of work covered book. Additional information on principal's participation in academic activities was sought from the students and the findings were as indicated in Table 4.

\begin{tabular}{|c|c|c|}
\hline $\begin{array}{c}\text { Activities } \\
\mathbf{n = 3 9 3}\end{array}$ & Frequency (F) & Percentage (\%) \\
\hline Officiating all examination release ceremonies & 380 & 96.7 \\
\hline Carrying out academic/ career counseling & 285 & 72.5 \\
\hline Allocated lessons on timetable & 273 & 69.5 \\
\hline Attending lessons allocated to teach & 255 & 64.9 \\
\hline Invigilating internal examinations & 250 & 63.6 \\
\hline Marking examination in his/ her subject area & 246 & 62.6 \\
\hline Setting examination in his/ her subject area & 239 & 60.8 \\
\hline
\end{tabular}

Table 4: Students' Responses on Principals' Participation in Academic Activities Source: Field Data (2016)

Information in Table 4 shows that 380 (96.7\%) of the students indicated that principals in their schools officiated all examination release ceremonies while $285(72.5 \%)$ of them reported that principals carried out academic/ career counseling in their schools. At the same time, $273(69.5 \%)$ of the students indicated that their school principals were allocated lessons on the timetable while another 255 (64.9\%) of them said that principals attended the allocated lessons to teach. In addition, $250(63.6 \%)$ of the students indicated that their principals invigilated internal examinations while $246(62.6 \%)$ of them reported that principals marked examinations in their subject area. Furthermore, 239 (60.8\%) of the students reported that principals set examinations in their subject area. 
In interview, one principal revealed, "It is not possible to go to class and teach. My work is too much. I have hired one teacher on board whom I use for teaching." Another principal said, "I teach my teaching subject. If you do not go to class you may lose the feel. In fact, I always have a candidate class and my stream always leads." Another principal indicated:

"I participate in all academic activities. Remember, I am teacher number one, so I teach, set exam, invigilate, mark and release results. I make sure I am around to release the results of all examinations."

The findings clearly show that principals were involved in most academic activities in their schools.

\subsection{Relationship between Principals' Participation in Academic Activities and Academic Performance}

Having examined the academic activities that principals participate in the study sought to establish whether the participation had any relationships with students' academic performance. This was done by use of cross tabulation, Pearson correlation and multi-linear regression analysis.

\subsubsection{Cross Tabulation of Principals' Participation in Academic Activities and School Categories}

Cross tabulation of principals' participation in academic activities and school performance categories was carried out to establish any relationships that existed. Table 5 has the findings for the same.

\begin{tabular}{|c|c|c|c|c|c|}
\hline \multirow{2}{*}{\multicolumn{2}{|c|}{ Academic Activities Participated by Principal }} & \multicolumn{3}{|c|}{ School Performance } & \multirow[t]{2}{*}{ Total } \\
\hline & & High & Average & Low & \\
\hline \multirow[t]{2}{*}{ Allocated lessons on timetable } & Count & 48 & 66 & 67 & 181 \\
\hline & Percentage & 26.5 & 36.5 & 37.0 & 100.0 \\
\hline \multirow{2}{*}{ Attending lessons to teach } & Count & 6 & 27 & 34 & 67 \\
\hline & Percentage & 9.0 & 40.3 & 50.7 & 100.0 \\
\hline \multirow{2}{*}{ Setting examination } & Count & 0 & 0 & 66 & 66 \\
\hline & Percentage & 0.0 & 0.0 & 100.0 & 100.0 \\
\hline \multirow[t]{2}{*}{ Invigilating examination } & Count & 60 & 42 & 0 & 102 \\
\hline & Percentage & 58.8 & 41.2 & 0.0 & 100.0 \\
\hline \multirow[t]{2}{*}{ Marking examination } & Count & 0 & 0 & 61 & 61 \\
\hline & Percentage & 0.0 & 0.0 & 100.0 & 100.0 \\
\hline \multirow{2}{*}{ Attending departmental/ subject meetings } & Count & 12 & 47 & 23 & 82 \\
\hline & Percentage & 14.6 & 57.3 & 28.0 & 100.0 \\
\hline \multirow[t]{2}{*}{ Officiating all exam release ceremonies } & Count & 66 & 61 & 67 & 194 \\
\hline & Percentage & 34.0 & 31.4 & 34.5 & 100.0 \\
\hline \multirow[t]{2}{*}{ Conducting career counseling } & Count & 36 & 47 & 22 & 105 \\
\hline & Percentage & 34.3 & 21.0 & 44.8 & 100.0 \\
\hline \multirow[t]{2}{*}{ Being an examiner with KNEC } & Count & 48 & 25 & 0 & 73 \\
\hline & Percentage & 65.8 & 34.2 & 0.0 & 100.0 \\
\hline
\end{tabular}

Table 5: Cross Tabulation of Principals' Participation in Academic Activities and School Academic Performance Source: Field Data (2016)

Results in Table 5 indicate that 48 (26.5\%), 66 (36.5\%) and 67 (37.0\%) of the teachers from HPS, APS and LPS respectively indicated that principals were allocated lessons on the timetable, which shows a negative relationship between allocating the principal lessons on the timetable and students' academic performance. At the same time, $6(9.0 \%), 27$ $(40.3 \%)$ and $34(50.7 \%)$ of the teachers from HPS, APS and LPS reported that their principals attended lessons to teach. This shows a negative relationship between principals attending lessons to teach and students' academic performance. Furthermore, $66(100 \%)$ of the LPS and none from APS and HPS indicated that their principals participated in setting examinations which shows a negative relationship between principals setting examination and students' academic performance. Another 60 (58.8\%), $42(41.2 \%)$ and $0(0.0 \%)$ of the teachers from HPS, APS and LPS respectively indicated that their principals invigilated examinations, which shows a positive relationship between the participation of the principal in invigilating examination and students' academic performance. A further $61(100 \%)$ of the LPS and none from APS and HPS reported that their principals participated in marking internal examinations which shows a negative relationship between principals marking examination and students' academic performance. At the same time, $12(14.6 \%), 47(57.3 \%)$ and 23 (28.0\%) of the teachers from HPS, APS and LPS respectively indicated that principals attended departmental/subject meetings, which shows no relationship between principals attending departmental/ subject meetings and students' academic performance. Another 66 (34.0\%), 61 (31.4\%) and 67 (34.5\%) of the teachers from HPS, APS and LPS respectively reported that principals officiated all exam release ceremonies. This indicates that there is no relationship between the principal officiating all exam ceremonies and students' academic performance. At the same time, 36 (34.3\%), 47 (21.0\%) and 22 $(44.8 \%)$ of the teachers from HPS, APS and LPS respectively indicated that principals conducted career counseling. This shows no relationship between the principal conducting career counseling and students' academic performance. Furthermore, $48(65.8 \%), 25(34.2 \%)$ and $0(0.0 \%)$ of the teachers from HPS, APS and LPS respectively revealed that their principals were examiners with KNEC. This shows a positive relationship between the principal being an examiner with KNEC and students' academic performance. 


\subsubsection{Pearson's Correlation between Principals' Participation in Academic Activities and Academic Performance}

Correlations between principals' participation in academic activities and students' academic performance were carried out. The findings are shown in Table 6.

\begin{tabular}{|c|c|c|c|}
\hline Academic Activities & $\mathbf{N}$ & Correlation Co-efficient (r) & Sig. \\
\hline Principal is allocated lessons on the timetable & 199 & 0.225 & $0.055^{*}$ \\
\hline Principal attends lessons to teach in his/ her subject area & 199 & -0.508 & $0.000^{*}$ \\
\hline Principal sets examination in his/ her subject area & 199 & -0.502 & $0.000^{*}$ \\
\hline Principal invigilates/ supervises examination & 199 & 0.731 & $0.000^{*}$ \\
\hline Principal marks examination in his/ her subject area & 199 & -0.474 & $0.000^{*}$ \\
& & & \\
\hline & 199 & 0.100 & $0.001^{*}$ \\
\hline Principal attend departmental / subject meetings in his/ her subject area & 199 & 0.114 & 0.108 \\
\hline Principal officiates all exam release ceremonies & 199 & 0.284 & $0.000^{*}$ \\
\hline Principal conducts academic/ career counseling & 199 & 0.542 & $0.000^{*}$ \\
\hline Principal is a KNEC examiner
\end{tabular}

Table 6: Correlation Coefficients of Students' Academic Performance across

Principal's Participation in Academic Activities

* Significant at $\mathrm{P}<0.05$

Source: Derived from Field Data (2016)

Results in Table 6 show that there were significant correlations at $p<0.05$ between the students' academic performance and principals' participation in academic activities: principal attending lessons to teach in his/ her subject area, principal setting examination in his/ her subject area, principal invigilating/supervising examination, principal marking examination in his/ her subject area, principal conducting academic/ career counseling and principal being a KNEC examiner. However, principal being allocated lessons on the timetable and principal officiating all exam release ceremonies had no significant relationships. It was also noted that principal setting examination in his/ her subject area, principal attending lessons to teach in his/ her subject area and principal marking examination in his/ her subject area had negative relationships with students' academic performance. This implies that principals who emphasized in participating in these activities recorded lower students' academic results compared to those who did not. On the other hand, principal conducting academic/ career counseling, attending departmental/subject meetings, invigilating/ supervising examination and being a KNEC examiner had positive relationships with students' academic performance. This means that principals who emphasized to participate in these activities, recorded higher academic performance compared to those who did not emphasize to participate in these activities. It is also necessary to note that all correlation coefficients $(r)$ were weak $(r>0.5)$ except principal being a KNEC examiner, principal invigilating/ supervising examination, principal setting examination in his/ her subject area and principal attending lessons to teach in his/ her subject area that had strong correlation coefficients $(\mathrm{r}<0.5)$.

\subsubsection{Regression Analysis}

In order to establish the relative contribution of each of academic activities that principals participated in on academic performance, a multi-linear regression analysis model was specified. According toKerlinger (1993), multiple regression attempts to determine whether a group of independent variables together predict a given dependent variables. This study adopted the backward elimination method which allows for the selection of variables for inclusion in the regression model that considered all independent variables and then eliminated those variables that did not make any significant contribution to prediction of the dependent variable (Gall, Gall and Borg, 2007; Hair et al. 2009).

Under this objective, this study sought to establish the relationship between principal participation in academic activities and students' academic performance. The relative effects of eight regressor [independent] variables:allocated lessons on the timetable, attending lessons to teach, setting examination, invigilating/ supervising examination, attending departmental/ subject meetings in his/ her subject area, officiating all exam release ceremonies, conducting academic/ career counseling and being a KNEC examinerwere considered together in one equation as predictors of [Y] students' academic performance (dependent variable). The main objective of using multiple regression analysis for estimation was to explain the factors that had a significant effect on students' academic performance (Kerlinger, 1993; Gall, Gall \& Borg, 2009).

The general statement of relationship was of the form: $Y=f\left(X_{1}, X_{2} \ldots \ldots \ldots . X_{n}\right)$. Where $Y$ was the criterion variable while $\mathrm{X}_{1}, \mathrm{X}_{2} \ldots \ldots \ldots . \mathrm{X}_{\mathrm{n}}$ represented the explanatory variables.

Results discussed below were the output of a simultaneous regression method, which required a researcher to specify the set of predictor variables that made up the model. The success of the model in predicting the criterion variable was then assessed. The following linear regression model was specified with KCSE mean scores as the dependent variable:

$Y=a_{1} X_{1}+a_{2} X_{2}+a_{3} X_{3}+a_{4} X_{4}+a_{5} X_{5}+a_{6} X_{6}+a_{7} X_{7}+a_{8} X_{8}+c$

Where;

$\mathrm{Y}=$ Academic performance (KCSE mean scores)

$\mathrm{X}_{1}=$ Allocated lessons on the timetable

$\mathrm{X}_{2}=$ Attending lessons to teach

$\mathrm{X}_{3}=$ Setting examination

$\mathrm{X}_{4}=$ Invigilating/ supervising examination

$\mathrm{X}_{5}=$ Attending departmental / subject meetings in his/ her subject area 
$\mathrm{X}_{6}=$ Officiating all exam release ceremonies

$\mathrm{X}_{7}=$ Conducting academic/ career counseling

$\mathrm{X}_{8}=$ Being a KNEC examiner

$\mathrm{c}=$ Constant; and $\mathrm{a}_{1} \ldots \mathrm{a}_{8}$ are regression coefficients

\section{Results}

The model entered eight explanatory variables for a linear relationship with students' academic performance. These were: allocated lessons on the timetable, attending lessons to teach, setting examination, invigilating/supervising examination, attending departmental/subject meetings in his/ her subject area, officiating all exam release ceremonies, conducting academic/ career counseling and being a KNEC examiner.

\begin{tabular}{|c|c|c|c|c|c|c|}
\hline Model & & Sum of Square & df & Mean Square & F & Sig \\
\hline 1 & Regression & 81.732 & 3 & 27.244 & 3.429 & 0.047 \\
\hline & Residual & 1557.220 & 196 & 7.945 & & \\
\hline & Total & 1638.952 & 199 & & & \\
\hline
\end{tabular}

Table 7

The F-ratio (between groups mean square) was 3.429 while the p-value was 0.047 . The probability of F-ratio (pvalue) of 0.047 was less than the significance level (critical value) of 0.05 . An examination of the ANOVA table, in this model revealed that the explanatory power of the model was high $(\mathrm{F}=3.429, \mathrm{p}<0.05)$; thus, the model could not be rejected.

\begin{tabular}{|c|c|c|c|c|}
\hline Model & R & R Square & Adjusted R Square & Std. Error of the Estimate \\
\hline 1 & .498 & .287 & .399 & 1.212 \\
\hline \multicolumn{4}{|c}{ Table 8} \\
\hline
\end{tabular}

Findings show an R-Square value of 0.287 , meaning that the independent variables (allocated lessons on the timetable, attending lessons to teach, setting examination, invigilating/supervising examination, attending departmental/ subject meetings in his/ her subject area, officiating all exam release ceremonies, conducting academic/ career counseling and being a KNEC examiner) explained $28.7 \%$ of the variation in academic performance.

\begin{tabular}{|c|c|c|c|c|c|}
\hline \multirow[t]{2}{*}{ Independent Variables } & \multicolumn{2}{|c|}{$\begin{array}{l}\text { Unstandardized } \\
\text { Coefficients }\end{array}$} & $\begin{array}{l}\text { Standardized } \\
\text { Coefficients }\end{array}$ & $\mathbf{T}$ & Sig. \\
\hline & B & Std. Error & Beta & & \\
\hline (Constant) & 4.095 & 206 & & 19.906 & .000 \\
\hline Allocated lessons on the timetable & .093 & .062 & .057 & 1.511 & .133 \\
\hline Attending lessons to teach & -.070 & .096 & -.070 & -.728 & .468 \\
\hline Setting examination & -.487 & .100 & -.486 & -4.892 & .000 \\
\hline Invigilating/ supervising examination & .600 & .045 & .635 & 13.192 & .000 \\
\hline $\begin{array}{l}\text { Attending departmental/ subject meetings in his/ her } \\
\text { subject area }\end{array}$ & .245 & .038 & .255 & 6.499 & .000 \\
\hline Officiating all exam release ceremonies & .036 & .151 & .012 & .241 & .810 \\
\hline Conducting academic/ career counseling & .147 & .036 & .155 & 4.017 & .000 \\
\hline Being a KNEC examiner & .216 & .041 & .221 & 5.340 & .000 \\
\hline
\end{tabular}

Table 9

Dependent Variable: KCSE Mean Scores (2010-2014)

Source: Field Data (2016)

Results show that the prediction equation for academic performance $(\mathrm{Y})$ becomes:

$\mathrm{Y}=4.095-0.486$ [setting examination] + 0.635 [invigilating/ supervising examination] + 0.255 [attending departmental/subject meetings in subject area] + 0.155 [conducting academic/ career counseling] + 0.221 [being a KNEC examiner].

This means that the KCSE examination mean score is predicted to reduce by 0.486 when setting examination by the principal goes up by one, increase by 0.635 when invigilation/ supervision of the examination by the principal increases by one, increase by 0.255 when attendance of the departmental/ subject meetings by the principal goes up by one, increase by 0.155 when conducting academic/ career counseling goes up by one and increase by 0.221 when being a KNEC examiner goes up by one.

The standardized beta ([) coefficients took on negative and positive values. However, only four variables significantly enhanced students' academic performance namely: invigilation/ supervision of internal examination, attending departmental/subject meetings, conducting academic/ career counseling and being a KNEC examiner $(\mathrm{p}<0.05)$. These findings are in line with Leithwood et al. (2008) who indicated that principals are essential for setting the tone and modeling good teaching practice. In addition, the findings concur with Plecki et al. (2005) and Knapp et al. (2004) who revealed that principals were an important element in the enhancement of academic performance through the actual participation. Several studies have also indicated that change or transfer of principal may reverse previous academic accomplishments achieved 
due to his personal initiatives (Macmillan et al., 2004; Shields, 2000; Hargreaves, 2005 and Leithwood et al., 2008). Fink and Brayman (2006) also reported that principals' participation in academic activities improves academic performance while Glasspool (2006) reported that proper planning of academic activities and participation by the principal enhances the achievement of academic goals set.

\section{Conclusions and Recommendations}

\subsection{Conclusions}

At the same time, this study established that there was a significant relationship between principals' participation in academic activities and students' academic performance. Principals being allocated lessons on the timetable, invigilating/ supervising examination, attending departmental/ subject meetings in his/ her subject area, officiating exam release ceremonies, conducting academic/ career counseling and being a KNEC examiner had significant relationship with students' academic performance. Principals' participation in academic activities explained $28.7 \%$ of the variation in academic performance among HPS, APS and LPS. Principal invigilating/supervising internal examinations, attending departmental/ subject meetings, conducting academic/ career counseling and being a KNEC examiner were good predictors of students' academic performance.

\subsection{Recommendations}

Based on the findings and conclusions, this study recommends that:

Principals should participate more in academic activities that enhance students' academic performance. These include: invigilating/ supervising examination, attending departmental/subject meetings in his/her subject area, conducting academic/ career counseling and being a KNEC examiner.

\section{References}

i. Akyeampong, K. (2007). 50 years of educational progress and challenge in Ghana. Paper presented at the Educational Expansion and Access in Ghana: a review of fifty years of challenge and progress, Parliament offices, Westminster, London.

ii. Bass, B. M. (1998). Transformational leadership: Industrial, military, and educational impact. Mahwah, NJ: Erlbaum.

iii. Bell, M.Q. (1999). Qualitative evaluation and research methods. (2nd Ed.). Newbury Park, CA: Sage Publications.

iv. Blaxter, L. (1996). How to research. Buckingham: Open University.

v. Bryman, A. and Cramer, D. (2001). Qualitative Data Analysis with SPSS release 10 for windows: A guide for Social Scientists. New York, NY, US: Routledge.

vi. Burns, J.M. (1978). Leadership. New York: Harper \& Row.

vii. Chimombo, M. (2009). The impact of teacher absenteeism on student performance. London: Route ledge.

viii. Clark, B.R. (2009). The Research Foundations of Graduate Education, Berkeley: Chicago University Press

ix. Creswell, J.W. (2012). Qualitative Inquiry and Research Design: Choosing among five Approaches (4th ed.). Thousand Oaks: Sage

x. Daaku, F. (2002). Mid-term stocktaking: Management for efficiency (Vol. 3, pp. 10-18). Accra, Ghana: ICU Office, Ghana Education Service.

xi. Dakar Forum (2001). The World Education Framework for action: Education in Tanzania: A Case Study Oxford: James Curry and Dar-es-Salam: MkakenaNyota

xii. Day, C. (2005). Sustaining success in challenging contexts: Leadership in English schools. Journal of Educational Administration, 43(6), 573-583.

xiii. Dooley, K. (2001). Statistical Sampling, 3rd Ed. Boston: McGraw-Hill.

xiv. Fink, D. \& Brayman, C. (2006). School Leadership Succession and the Challenges of Change. Educational Administration Quarterly. 42 (1): 62-89.

xv. Gall, M.D., Gall, J.P. and Borg, W.R. (2007). Educational Research: An Introduction, 8th Edition. Harlow: Prentice Hall

xvi. Ghauri, P. and Gronhaug, K. (2005). Research Methods in Business: A Practical Guide. 3rd Edition. Harlow: Prentice Hall

xvii. Glasspool, T. S. (2006). Socialization of Pennsylvania High School Principal Succession. (Dissertation). University of Pittsburgh.

xviii. Hague,J.W. (1998). Qualitative inquiry and research design. CA: Sage.

xix. Hair, J.F., Black, W.C., Babin, B. J. and Anderson, R.E. (2009). Multivariate Data Analysis, 7th Edition. Harlow: Prentice Hall

xx. Hargreaves, A. (2005). Leadership Succession. The Educational Forum. 69: 163-173.

xxi. Israel, G.D. (1992). Determining Sample Size. http:/ / edis.infas.ufl.edu/pdffiles/ PD00600. Retrieved on June 1, 2014.

xxii. Kathuri, J.N. and Pals, D.A. (1993). Introduction to Educational Research. Njoro: Egerton University Press

xxiii. Keeves, J.P. (1997). Educational Research Methodology and Measurement: An Kennesaw State University.

xxiv. Kerlinger F.N. (1993). Foundation of Behavioral Research. New York: Holt Reinehant and Winston.

xxv. Knapp, M. S., Elfers, A. M. and Plecki, M. L. (2004). Preparing for reform, supporting teacher's work: Surveys of Washington state teachers, 2003-04 school years. Seattle, WA: University of Washington.

xxvi. Kosecoff, K. (1998). How to conduct surveys: A step by step guide. Buckingham, Oxford university press. 
xxvii. Kothari, C.R (2004). Research Methodology. Methods and Techniques, 2nd edition, new Delhi, New age international Publishers.

xxviii. Koul, L. (1992). Methodology of Educational Research (2nd Ed). New Delhi: Vikas Publishing House Development Ltd.

xxix. Leithwood, K., Harris, A. and Hopkins, D. (2008). Seven strong claims about successful school leadership. School Leadership \& Management. 28 (1):27 - 42.

xxx. Lumosi, B. A. and Mukonyi, P.W. (2015). Quality Monitoring in Secondary Education in Kenya: A Comparative Analysis of Public Schools in Kakamega East and Kakamega Central Sub-Counties of Kakamega County. International Journal of Education and Research, Vol. 3 (1), 411-420.

xxxi. Macmillan, R. B., Meyer, M. J. and Northfield, S. (2004). Trust and Its Role in Principal Succession: A Preliminary Examination of a Continuum of Trust. Leadership and Policy in Schools. 3(4): 275-294.

xxxii. Mobegi, O.F., Ondigi, B.A. and Oburu, O.P. (2010). Secondary school headteachers' quality assurance strategies and challenges in Gucha district, Kenya. Educational Research and Review, Vol.5 (2), 408-414.

xxxiii. MoE. (2011). Diploma in Education Management for Secondary Schools. Nairobi: Kenya Literature Bureau.

xxxiv. Mugenda, O.M. and Mugenda, A. G. (2003), Research Methods: Quantitative and Qualitative Approaches, 2nd edition, Nairobi, Acts press.

xxxv. Nassiuma, D.K., (2000). Survey Sampling: Theory and Practice. Nairobi, Nairobi University press

xxxvi. Okoth, P.G. (2012). Research as a Cornerstone of Quality Assurance in University Education with specific Reference to Uganda Martyrs University. Journal of Social Science and Sustainable Development.5:37-57.

xxxvii. Orodho, J.A. (2009). Techniques of Writing Research Proposal and Reports in Education and Social Sciences. Nairobi: Kenezja Publishers

xxxviii. Plecki, M. L., Elfers, A. M., Loeb, H., Zahir, A. and Knapp, M.S. (2005, March). Teacher Retention and Mobility: A Look Inside and Across Districts and Schools in Washington State. Seattle, WA: University of Washington.

xxxix. Sarantakos, S. (1998). Social Research (2nd Ed.). London: Macmillan press

xl. Shields, B.A. (2000). Administrator Turnover: Causes and Implications (dissertation), State University of New York at Buffalo.

xli. World Bank (2008). Governance, Management and Accountability in secondary Education in Sub-Saharan Africa. Washington D. C: World Bank.

xlii. World Competitiveness Report (2009). Competitiveness factors- online-http: //www 04.imd. ch/ documents/ wcy/ content/ ma.pdf-accessed 15/10/2011.

xliii. Zeller, R.A. (1997). In Keeves, J.P. (Ed.), Educational Research Methodology. Buckingham, Oxford university press. 